Арбузова Г. А., Горбунова А. И., Чепинога В. В. Рогульник плавающий (Trapa natans L., Lythraceae) в Иркутской области

УДК 581.9(571)

DOI 10.18101/2587-7143-2019-1-29-36

\title{
РОГУЛЬНИК ПЛАВАЮЩИЙ (TRAPA NATANS L., LYTHRACEAE) В ИРКУТСКОЙ ОБЛАСТИ
}

\section{Г. А. Арбузова, А. И. Горбунова, В. В.Чепинога}

(C) Арбузова Галина Андреевна

студент,

Иркутский государственный университет

Россия, 664003, г. Иркутск, ул. К. Маркса, 1

e-mail: mingronland@mail.ru

\section{(C) Горбунова Анна Ивановна}

студент,

Иркутский государственный университет

Россия, 664003, г. Иркутск, ул. К. Маркса, 1

e-mail:gorbunova61.98@mail.ru

\section{(C) Чепинога Виктор Владимирович}

доктор биологических наук

Институт географии им. В.Б. Сочавы СО РАН

Россия, 664033, г. Иркутск, ул. Улан-Баторская, 1

Иркутский государственный университет

Россия, 664003, г. Иркутск, ул. К. Маркса, 1

e-mail: victor.chepinoga@gmail.com

\section{Для цитирования:}

Арбузова Г. А., Горбунова А. И., Чепинога В. В. Рогульник плавающий (Trapa natans L., Lythraceae) в Иркутской области // Вестник Бурятского государственного университета. Биология, география. 2019. № 1. С. 29-36.

Trapa natans s.1. - вид, включенный в Красные книги регионов Байкальской Сибири. В Иркутской области этот вид известен только из оз. Солонецкое Тайшетского района. В литературе растения из этого озера принято относить к $T$. sibirica Flerow, однако специальных исследований для этого не проводилось. На основе материалов 2017 г. и более ранних наблюдений, нами подтверждена таксономическая принадлежность рогульника из оз. Солонецкого к T. sibirica и дана характеристика динамики популяций вида в озере. Учитывая исчезновение сообществ рогульника и продолжающееся сокращение численности и размеров популяций, начиная с 2004 г, существует опасность полного исчезновения T. sibirica из озера, а также из состава флоры Иркутской области.

Ключевые слова: Trapa natans, Trapa sibirica, оз.Солонецкое, Красная книга, Иркутская область, Байкальская Сибирь 
Введение

Род рогульник, чилим или водяной орех (Trapa L.) объединяет водные растения с собранными в розетки и плавающими на поверхности воды листьями и длинным, от 1 до 5 м, тонким стеблем, укорененным в донном грунте. Наиболее примечательны у этого растения плоды, формирующиеся на месте мелких белых цветков. Плоды крупные, до 3 см и более, ореховидные (с одним семенем) и 2-4 супротивными мощными выростами - рогами, увенчанными на концах елочковидными гарпунчиками (Цвелев, 1995; Hummel, Kiviat, 2004). В качестве пищевого растения водяной орех известен уже, по меньшей мере, 3000 лет и являлся важным источником крахмала в питании жителей Европы вплоть до конца XIX века (Karg, 2006), а в Индии до сих пор широко разводится в аквакультуре (Small, 2012). Использование в пищу орехов из естественных популяций привело к тому, что на территории Европы это растение попало в число исчезающих и находится под охраной во многих европейских странах. Такова ситуация в умеренных широтах исходного ареала рода, который охватывает Евразию и Африку. Кроме того, рогульник интродуцирован в Австралию и Северную Америку, где относится к агрессивным инвазивным растениям (Les, Mehrhoff, 1999; Hummel, Kivait, 2004).

Еще недавно род Trapa рассматривался в составе монотипного семейства Trapaceae Dumort. (Takhtajan, 2009). Однако молекулярные исследования показали, что рогульник, как соннератия (Sonneratia) и гранат (Punica), также выделявшиеся в монотипные семейства (Sonnerataceae и Punicaceae, соответственно), без сомнения, относится к семейству дербенниковые (Lythraceae J.St.-Hil.) (Graham et al., 2005). Именно в таком составе семейство вошло в современную филогенетическую классификацию APGIV (Chase et al., 2016).

По причине морфологической вариабельности, внутриродовая систематика Trapa весьма запутана с прямо противоположными точками зрения на объем видов. Сторонники первой рассматривают все рогульники в рамках одного вида Trapa natans L. s.1., либо выделяют два вида T. natans и T. incise Sieb \& Zucc., a всю вариабельность первого описывают несколькими разновидностями (Hassler, 2019). Сторонники противоположной точки зрения придают ранг вида многочисленным морфотипам, встречающимся на протяжении ареала рода. В этом случае количество видов в роде достигает 50 (Цвелев, 1995). Например, только для территории Восточной Европы и Северной Азии Н.Н. Цвелев приводит 25 видов (Цвелев, 1993). Учитывая большой возраст рода, ископаемые представители которого известны с олигоцена, или даже мела (Васильев, 1960), можно ожидать, что действительное разнообразие рода находится где-то между этими крайними значениями 2 и 50. Очевидно, решение этого вопроса возможно лишь молекулярнобиологическими методами, показавшими свою перспективность в выявлении и оценке генетического разнообразия представителей рода (Xueetal., 2017).

На территории Сибири рогульник распространен весьма спорадично, почти единодушно относится к реликтовым видам, исчезновению которого, по-видимому, в значительной степени способствовала деятельность человека (Цвелев, 1964). В большинстве Сибирских регионов рогульник включен в Красные книги и известен из немногих местонахождений. Это относится и к территории Байкальской Сибири, включающей Иркутскую область, Республику 
Арбузова Г. А., Горбунова А. И., Чепинога В. В. Рогульник плавающий (Trapa natans L., Lythraceae) в Иркутской области

Бурятия и Забайкальский край (Малышев, Пешкова, 1984). На территории Забайкальского края, T. natans s.l. известен из трех озер (Лесков, 2017), в Бурятии - из единственного озера в Муйско-Куандинской впадине (Чепинога, 2013). В Иркутской области этот вид также известен только из одного водоема - это оз. Солонецкое на крайнем западе области, в 2 км от границы с Красноярским краем (Ляхова, 2010). По умолчанию популяции рогульника из Байкальской Сибири отнесены к расе T. sibirica Flerow (Цвелев, 1993; Чепинога, 2015). Данная статья посвящена уточнению таксономической принадлежности и описанию состояния популяций рогульника в оз. Солонецком.

\section{Район исследования}

Озеро Солонецкое (N56.933096 E97.675964) расположено в Тайшетском районе у западной границы Иркутской области в пойме р. Бирюса. Озеро имеет вытянутую и изогнутую в субширотном направлении форму, типичную для старичных озер. Глубина озера, по нашим данным, достигает не менее 3,5 м и подстилается мощными отложениями ила. Общая длина озера составляет порядка 3,3 км, из которых основной водоем составляет лишь половину этой длины (1,7 км). Озеро является излюбленным местом отдыха местных жителей - небольшое с. Шелаево с населением чуть больше 600 чел. начинается уже в 300 м от озера. Более крупный населенный пункт, пос. Новобирюсинск, расположен в 3 км к северо-востоку на правом берегу р. Бирюса.

\section{Материалы и методы}

Материалами послужили 13 прошлогодних плодов рогульника, которые удалось собрать 6 августа 2017 г. в оз. Солонецком. Для характеристики сообществ с доминированием рогульника использованы четыре геоботанических описания, выполненные В.В. Чепиногой 17 августа 2004 г. Использованы также материалы наблюдений за состоянием популяций за те же годы.

Морфометрические показатели плодов сняты в соответствии с работой А. П. Лескова (2010). Классификационная принадлежность растительных сообществ определена в системе флористической классификации (подход Ж. Браун-Бланке) по В. В. Чепиноге (2015).

\section{Результаты и обсуждение}

Как видно из морфометрических показателей плодов, приведенных в табл. 1 , плоды рогульника из оз. Солонецкого отличались несколько более крупными размерами по сравнению с орехами из оз. Комогорцевское в Нерчинском районе Забайкальского края (Лесков, 2010). В целом, размеры как забайкальского, так и иркутского рогульника вписываются в параметры T. sibirica (Цвелев, 1995). К сожалению, учтенные параметры не охватывают все основные диагностические признаки, позволяющие отнести растения к одному из мелких видов. Прочими важными признаками является наличие хорошо развитой скульптуры (бугры, вмятины и гребни) на твердой оболочке плода, а также достаточно широкая коронка (6-14 мм диам.), венчающая верхушку плода (Цвелев, 1995). Как видно на Рис. 1 и 2, плоды с оз. Солонецкое имеют и достаточно крупную коронку (почти равную ширине плода без рогов), и соответствующую скульптуру поверхности. Все это позволяет с уверенностью отнести роголистник из оз. Солонецкое к виду T. sibirica. 
Таблица 1

Морфометрические показатели плодов рогульника (Trapa natans s.1.) с о3. Солонецкое (Иркутская обл.)

\begin{tabular}{|c|c|c|c|c|c|}
\hline \multirow{2}{*}{ № плода } & \multirow{2}{*}{$\begin{array}{c}\text { Высота } \\
\text { плода }\end{array}$} & $\begin{array}{c}\text { по концам } \\
\text { верхних } \\
\text { рогов }\end{array}$ & $\begin{array}{c}\text { между основа- } \\
\text { ниями верх- } \\
\text { них рогов }\end{array}$ & $\begin{array}{c}\text { по концам } \\
\text { нижних } \\
\text { рогов }\end{array}$ & $\begin{array}{c}\text { между основа- } \\
\text { ниями нижних } \\
\text { рогов }\end{array}$ \\
\hline 1 & 34 & 45 & 21 & 47 & 18 \\
\hline 2 & 29 & 45 & 25 & 44 & 16 \\
\hline 3 & 30 & 49 & 23 & 38 & 15 \\
\hline 4 & 34 & 46,5 & 20 & 41,5 & 15 \\
\hline 5 & 30 & 48 & 23 & 39 & 13 \\
\hline 6 & 28 & 48 & 28 & 38 & 16 \\
\hline 7 & 30,5 & 44 & 19 & 42 & 13 \\
\hline 8 & 28 & 40 & 16,5 & 42 & 13 \\
\hline 9 & 27 & 40 & 16 & 38 & 15 \\
\hline 10 & 29 & 39 & 17 & 39 & 13 \\
\hline 11 & 24 & 39,5 & 20 & 41 & 17,5 \\
\hline 12 & 19 & 39 & 14 & 28 & 10 \\
\hline 13 & 21 & 31 & 14,5 & 29 & 9 \\
\hline
\end{tabular}

Среднее

\begin{tabular}{|c|c|c|c|c|c|}
\hline $\begin{array}{c}\text { оз. Солонецкое, } \\
2017\end{array}$ & 28,0 & 42,6 & 19,8 & 39,0 & 14,1 \\
\hline $\begin{array}{c}\text { оз. Комогорцев- } \\
\text { ское, } 2004^{* *}\end{array}$ & $25 \pm 0,2$ & $38 \pm 0,3$ & $18 \pm 0,3$ & $34 \pm 0,4$ & $13 \pm 0,2$ \\
\hline $\begin{array}{c}\text { оз. Комогорцев- } \\
\text { ское, } 2005^{* *}\end{array}$ & $26,5 \pm 0,3$ & $39,4 \pm 0,4$ & $18,8 \pm 0,3$ & $34,7 \pm 0,4$ & $15,4 \pm 0,3$ \\
\hline
\end{tabular}

Примечание. *Ширина плода от окончаний рогов определялась без учета длины «гарпунчиков». **Значения приведены по: Лесков, 2010.

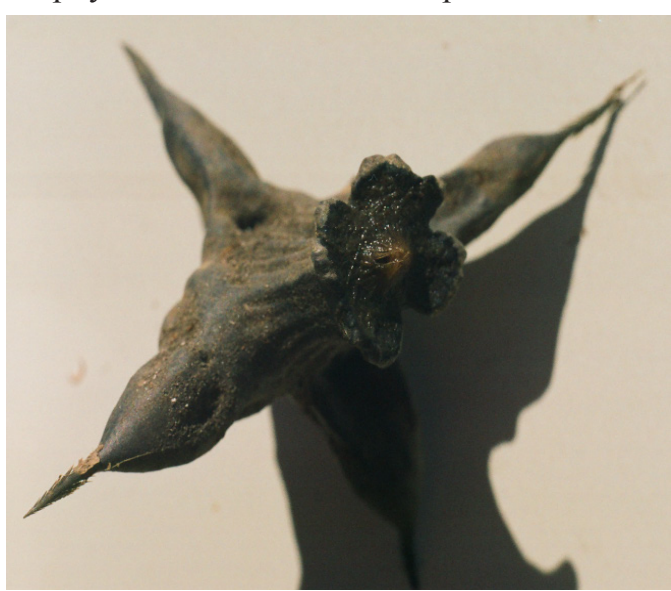

a

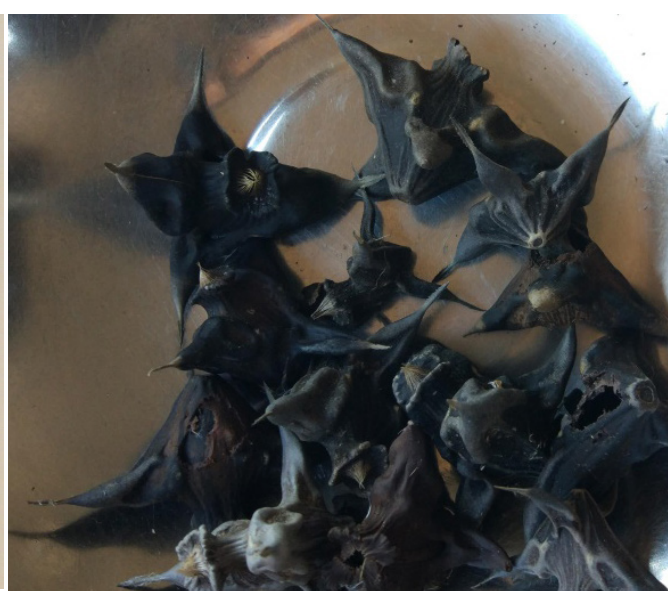

Рис. 1. Внешний вид плодов рогульника (Trapa natans s.1.) из оз. Солонецкое (Иркутская обл.) (фото: В. Чепинога, 2017 г.). 
Арбузова Г. А., Горбунова А. И., Чепинога В. В. Рогульник плавающий (Trapa natans L., Lythraceae) в Иркутской области

Поскольку геоботанические описания сообществ рогульника на оз. Солонецком были опубликованы ранее (Chepinoga et al., 2013; Чепинога, 2015), в данной статье мы дадим лишь краткую характеристику сообществ. Синтаксономическое положение сообществ с доминированием Trapa natans s.1. в соответствии с флористической классификацией (подход Браун-Бланке) имеет следующий вид:

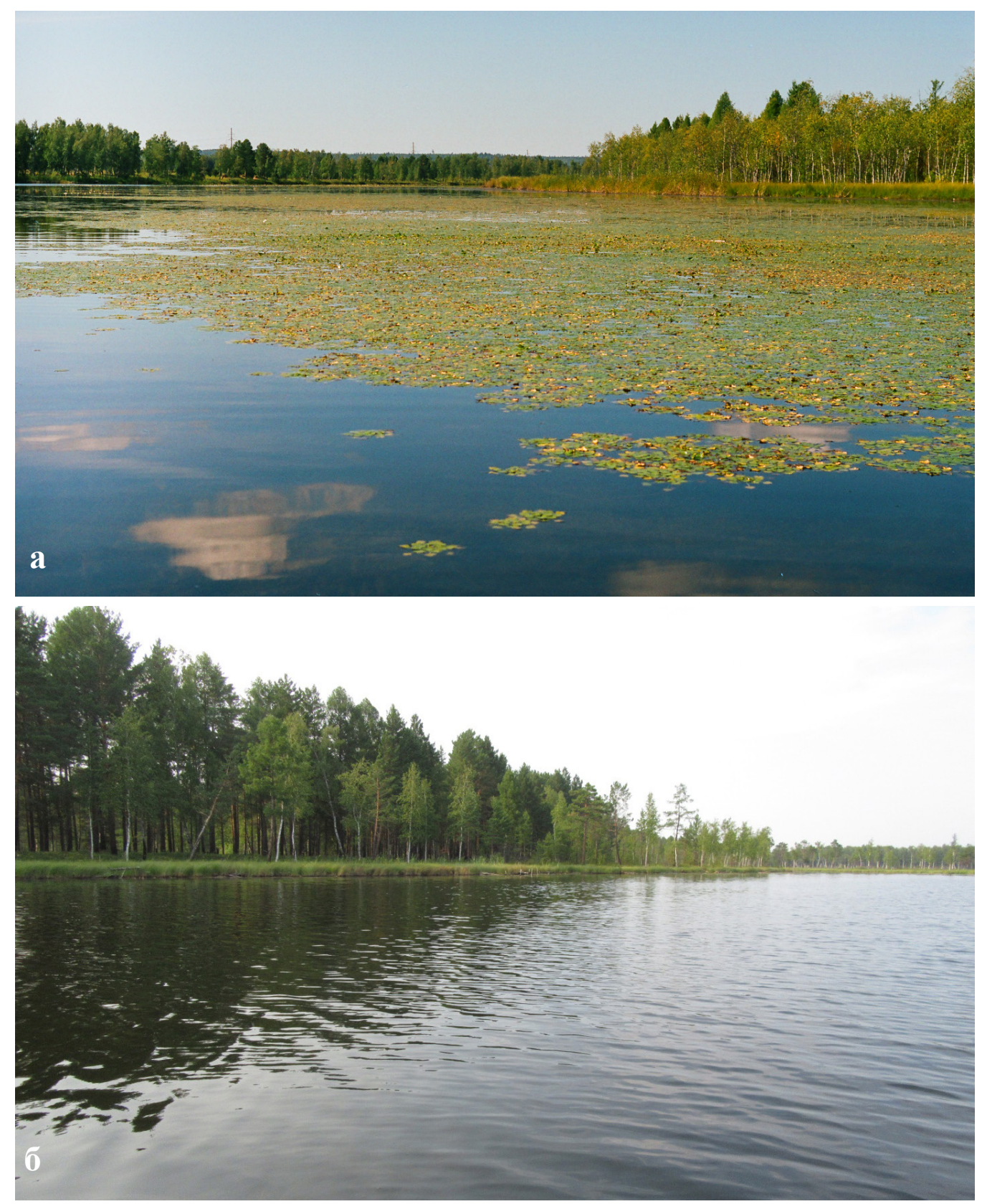

Рис. 2. Сообщества рогульника на оз. Солонецком в августе 2004 г. (а) и полное их отсутствие в августе 2017 года (б). 
Класс Potamogetonetea Klika in Klika et Novák 1941

Порядок Potamogetonetalia W. Koch 1926

Союз Nymphaeionalbae Oberdorfer 1957

Ассоциация Trapetum natantis Kárpáti 1963,

где союз Nymphaeion albae объединяет сообщества водных растений, с листьями плавающими на поверхности воды, порядок Potamogetonetalia охватывает как плавающую, так и погруженную водную растительность водоемов с более или менее постоянным уровнем воды, а класс Potamogetonetea включае твсе сообщества укореняющихся водных растений, произрастающих в пресной и солоноватой воде.

По сложившейся традиции, сообщества всех мелких видов комплекса T. natans описываются под названием Trapetum natantis Kárpáti 1963. Чтобы не инициировать номенклатурных изменений, сообщества T. sibirica мы также оставляем в рамках этой ассоциации в широком смысле.

Сообщества Trapetum natantis Kárpáti 1963 из оз. Солонецкое маловидовые, включают не более 3-4 видов. Хотя описания выполнялись на пробных площадях 16 и 25 м²$^{2}$ площадь самих сообществ могла превышать несколько сотен квадратных метров (рис. 2a). Ценозы приурочены к наиболее глубоким, центральным участкам озера; описания выполнены на глубинах 200-270 см. Донные грунты, как и повсеместно в озере - мощные отложения ила (Чепинога, 2015).

После описания сообщества T. natans в 2004 г., озеро посещалось нами в 2007 г. и уже было заметно снижение площади популяций и обилия зрелых орехов.В августе 2017 г. было обследовано все озеро, но ни одного участка, где рогульник имел бы приемлемое обилие не найдено. Обнаружены лишь отдельные розетки растений и полтора десятка прошлогодних орехов, использованных для морфометрического анализа. Отрицательная динамика популяций рогульника вызывает тревогу за выживание этого уникального для региона растения.

Одной из причин сокращения численности рогульника, которую в ходе опроса называли местные жители, является использование орехов в пищу. Однако в последние годы орехи не образуются на озере в масштабах пригодных для сбора, а сокращение популяции продолжается. Очевидно, следует не только полностью исключить сбор орехов, но и обеспечить отсутствие беспокойства вегетирующих растений рыбачьими и прогулочными лодками. В противном случае, флора Иркутской области может лишиться одного из древних видов растений, известных только с оз. Солонецкого.

\section{Заключение}

Растения рогульника плавающего из оз. Солонецкого, безусловно, относятся к мелкому виду Trapa sibirica Flerow. Постепенное сокращение популяций рогульника, наблюдаемое в течение последних 14 лет, привело к тому, что наблюдавшиеся в 2004 г. сообщества с доминированием T. sibirica на озере уже отсутствуют, и само растение стало весьма редким. Если в ближайшее время рогульник не начнет восстанавливаться, он может выпасть из состава флоры озера.

Работа выполнена в рамках государственного задания Института географии им. В.Б. Сочавы СО РАН (тема № 0347-2016-003). 
Арбузова Г. А., Горбунова А. И., Чепинога В. В. Рогульник плавающий (Trapa natans L., Lythraceae) в Иркутской области

\section{Литература}

1. Васильев В.Н. Водяной орех и перспективы его культуры в СССР. М., Л., 1960. 100 с.

2. Лесков А.П. Рогульник плавающий, водяной орех // Красная книга Забайкальского края. Растения / под ред. О.А. Полякова и др. Новосибирск: Дом мира, 2017. С. 165-166.

3. Лесков А.П. Экология и биология Trapa natans L. (Восточное Забайкалье) // Ученые записки Забайкальского государственного педагогического университета. Серия Естественные науки. 2010. № 1. С. 140-146.

4. Ляхова И.Г. Рогульник плавающий // Красная книга Иркутской области / отв. ред. О.Ю. Гайкова. Иркутск: Время странствий, 2010. С. 271.

5. Малышев Л.И., Пешкова Г.А. Особенности и генезис флоры Сибири. Предбайкалье и Забайкалье. Новосибирск: Наука, 1984. 264 с.

6. Цвелев Н.Н. О роде Trapa (Trapaceae) в Восточной Европе и Северной Азии // Новости систематики высших растений. СПб.: Наука, 1993. Т. 29. С. 99-107.

7. Цвелев Н.H. О способе распространения водяного ореха (Trapa L.) в прошлом и вымирании его в историческое время // Ботанический журнал. 1964. Т. 49, № 9. С. 13381340 .

8. Цвелев Н.Н. Рогульниковые, или Водноореховые - Trapaceae Dumort. // Сосудистые растения советского Дальнего Востока. Т. 7 / отв. ред. С.С. Харкевич. СПб.: Наука, 1995. C. 241-244.

9. Чепинога В.В. Водяной орех (рогульник) сибирский (в. о. плавающий) // Красная книга Республики Бурятия: редкие и находящиеся под угрозой исчезновения виды растений, животных и грибов / отв. ред. Н.М. Пронин. Улан-Удэ: Бурят.кн. изд-во, 2013. С. 628.

10. Chepinoga V.V., Bergmeier E., Rosbakh S.A., Fleckenstein K.M. Classification of aquatic vegetation (Potametea) in Baikal Siberia, Russia, and its diversity in a North Eurasian context // Phytocoenologia. 2013. Vol. 43, № 1-2. P. 127-167.

11. Graham Sh.A., Hall J., Sytsma K., Shi S.-H. Phylogenetic Analysis of the Lythraceae Based on Four Gene Regions and Morphology // International Journal of Plant Sciences. 2005. Vol. 166, №6. P. 995-1017.

12. Hassler M. World Plants: Synonymic Checklists of the Vascular Plants of the World (version Apr 2018) //Roskov Y., Ower G., Orrell T., Nicolson D., Bailly N., Kirk P.M., Bourgoin T., DeWalt R.E., Decock W., Nieukerken E. van, Zarucchi J., Penev L. (eds.) (2019). Species 2000 \& ITIS Catalogue of Life. [Электронный pecypc].URL: www.catalogueoflife.org/col. Species 2000: Naturalis, Leiden, the Netherlands. ISSN 2405-8858. (дата обращения 29.01.2019).

13. Hummel M.,Kiviat E. Review of world literature on water chestnut with implications for management in North America // Journal of Aquatic Plant Management. 2004. Vol. 42. P. 17-28.

14. Karg S. The water chestnut (Trapa natans L.) as a food resource during the 4th to 1 st millennia BS at Lake Federsee, Bad Buchau (southern Germany) // Environmental Arhcaeology. 2006. Vol. 11. P. 125-130.

15. Les D. H.; Mehrhoff L. J. Introduction of nonindigenous aquatic vascular plants in Southern New England: a historical perspective // Biological Invasions. 1999. Vol. 1, № 2/3. P. 281-300.

16. Small E. Top 100 exotic food plants. Boca Raton, Fla.: CRS Press, 2012. 708 p.

17. Takhtajan A. Flowering plants. $2^{\text {nd }}$ ed. New York: Springer, 2009. 871 p. 
18. Chase M. W., Christenhusz M. J. M., Fay M. F., Byng J. W., Judd W. S., Soltis D. E., Mabberley D. J., Sennikov A. N., Soltis P. S., Stevens P. F. An update of the Angiosperm Phylogeny Group classification for the orders and families of flowering plants: APG IV // Botanical Journal of the Linnean Society. 2016. Vol. 181, № 1. P. 1-20.

19. XueZh.-Q., Xue J.-H., Kryukova M.V., Ma K.-P.The complete chloroplast DNA sequence of Trapa maximowiczii Korsh. (Trapaceae), and comparative analysis with other Myrtales species // Aquatic botany. 2017. Vol. 143. P. 54-62.

\title{
THE WATER CHESTNUT (TRAPA NATANS L., LYTHRACEAE) IN IRKUTSK REGION
}

\section{G. A. Arbusova, A. I. Gorbunova, V. V. Chepinoga}

\section{Galina A. Arbusova}

student

Irkutsk State University

Russian Federation, Irkutsk 664003, Karl Marx Str., 1

e-mail: mingronland@mail.ru

\author{
Anna I. Gorbunova \\ student \\ Irkutsk State University \\ Russian Federation, Irkutsk 664003, Karl Marx Str., 1 \\ e-mail: gorbunova61.98@mail.ru \\ Victor V. Chepinoga \\ Dr. Sci. (Biol.) \\ V. B. Sochava Institute of Geography SB RAS \\ Russian Federation, Irkutsk 664033, Ulan-Batorskaya Str., 1 \\ Irkutsk State University \\ Russian Federation, Irkutsk 664003, Karl Marx Str., 1 \\ e-mail: victor.chepinoga@gmail.com
}

Trapa natans s.l. is a species included in Red Books of all regions of the Baikal Siberia. From Irkutsk Region, this species is known only from the Solonetskoye Lake (Taishetskii Raion). Traditionally, plants from this lake attributed to the small species $T$. sibirica Flerow, however no special studied have been conducted. Basing on original data from 2017 and earlier observations, we have confirmed that the water chestnut from Solonteskoye lake belong to T. sibirica. Besides, we characterize the population dynamics of the species, i.e. we note the disappearance of communities with dominance of $T$. sibirica, and continuous decline of the species abundance. We stress that there is a danger of extinction of the water chestnut from the Solonetskoye lake and accordingly from flora of the Irkutsk Region.

Keywords: Trapa natans, Trapa sibirica, Solonetskoye lake, Red book, Irkutsk Region, Baikal Siberia. 